Section Editors

David C. Spencer, MD

Steven Karceski, MD

Steven Karceski, MD

\title{
How comorbid conditions affect the choice of treatment in multiple sclerosis
}

A person can have more than one medical illness at the same time. For instance, a person could have headaches and also have low thyroid. In some cases, the medical illnesses are unrelated. In other instances, the comorbid illnesses occur together more often than by chance alone. In medicine, comorbid illnesses are very common. Many prior Patient Pages have discussed some of these associations. For people with multiple sclerosis (MS), having a comorbid medical condition is common. In some studies, $40 \%-66 \%$ of people with MS will also have another, associated, medical condition.

It is not uncommon to find that a person with 2 comorbid diseases fares less well than a person with just 1 disease. There are many reasons why this might be true. For instance, a person with multiple medical illnesses may simply be sicker and therefore do less well overall. For instance, some studies have shown that people with MS and a comorbid illness have more severe disability and an increased number of hospitalizations.

In others, the combination of illnesses might affect which medications should be chosen. In others, the comorbidities may affect whether a person can tolerate certain medications or treatments. This would influence whether or not a person could stay on a given therapy. In their study, "Assessing association of comorbidities with treatment choice and persistence in MS: a real-life multicenter study," Dr. Laroni and her colleagues ${ }^{1}$ tried to evaluate how a comorbid illness in a person with MS might affect the choice of treatment and how it affects whether a person with MS stays on a particular therapy.

HOW WAS THE STUDY DONE? Dr. Laroni and her colleagues work in Italy. They found patients at 20 MS centers across Italy. They only evaluated people who were newly diagnosed with MS between 2010 and 2016. During the 6-year period, the researchers identified 2,076 people with newly diagnosed MS. The diagnosis of MS was made using standard diagnosis protocols such as the 2005 and 2010 MacDonald Criteria.

The medical records of this group were carefully reviewed. The researchers looked at many factors including age, sex, time between onset of symptoms and diagnosis, disability scores (using the standard
Expanded Disability Status Scale), presence of active central nervous system abnormalities on an MRI, presence of comorbidities, and choice of first treatment.

As expected for people with newly diagnosed MS, the group was young. Their average age was 35.3 years. A total of $64.9 \%$ were women. The average time from diagnosis to the start of MS treatment was less than 1 year ( 0.82 years). Of the 2,076 , the authors found that $1,877(90.4 \%)$ of the group had medical records that also described whether or not there was a comorbid medical illness. A total of $23.9 \%$ of these patients had at least 1 comorbid illness. A total of $5.2 \%$ had 2 or more comorbidities.

WHAT WERE THE RESULTS? First, the group looked at the kind of comorbidities people with MS were likely to have. MS is an autoimmune disease. It was interesting that $7.2 \%$ of this group had a second comorbid autoimmune illness. A total of $5.8 \%$ had a psychiatric illness. Following this, $5.1 \%$ had cardiovascular disease, $2.8 \%$ had a metabolic illness, $2.3 \%$ had another neurologic disease, and $1.2 \%$ had a gastrointestinal illness. When Dr. Laroni and her colleagues looked at the associated autoimmune illnesses, autoimmune thyroid disease accounted for almost two-thirds (62.5\%). In the psychiatric group, depression accounted for $53.5 \%$ and anxiety for $17 \%$. In those with a comorbid neurologic disease, migraine was most common (70.4\%), followed by epilepsy at $15.9 \%$.

Next, Dr. Laroni and her colleagues evaluated the relationship between the presence of a comorbidity and the type of MS treatment. They found no differences. In other words, having MS and a comorbid medical illness did not seem to influence the choice of first treatment for MS.

Next, Dr. Laroni and her colleagues looked at MS, comorbidities, and the likelihood that a person might switch MS treatment. In doing this analysis, the authors found that half $(47.7 \%)$ of patients switched their MS treatment within 3 years. About half of the group that switched $(26.4 \%)$ did so because of ineffectiveness. The others switched due to side effects $(18.9 \%)$ or pregnancy (4\%). When a statistical analysis was done, Dr. Laroni and her colleagues found that people with comorbidities did not switch because the treatment because of 
ineffectiveness. However, the people with MS who also had a comorbid illness were more likely to switch due to side effects.

WHAT DOES THIS MEAN? Dr. Laroni and her colleagues evaluated many factors, and found that people with MS who also have a comorbid medical illness are more likely to switch their treatment of
MS due to side effects. This information is new and important: there are no studies that have looked at the reasons why people with MS change their treatments. The authors note that more study is needed in this area. Perhaps by better understanding the reasons why people with MS switch their therapies, doctors will be able to design better treatment plans. 


\section{PATIENT PAGE}

Section Editors

David C. Spencer, MD

Steven Karceski, MD

Steven Karceski, MD

\section{About multiple sclerosis}

WHAT IS MULTIPLE SCLEROSIS? Multiple sclerosis (MS) is an inflammatory disease that affects the central nervous system (the brain and spinal cord). It affects women about twice as often as men. It usually is diagnosed around age 30 .

The cause of MS is unknown. However, there are several clues about how MS begins. For instance, MS occurs more often in people who live in northern latitudes. Some have proposed that northerners are exposed to an infection in childhood. The immune system forms antibodies to the infectious agent (it could be a bacteria or virus).

Later in life, for reasons that are unclear, the antibodies attach to a protein in the myelin coating of the axons. The body becomes confused, and begins destroying the much-needed myelin. Without myelin, nerve cell signals travel much more slowly. This results in weakness, numbness, and other neurologic symptoms.

Something in our genes may be responsible for MS. For instance, MS is more likely to occur in first-degree relatives (mother, father, brother, or sister) than in distant relatives or unrelated individuals. A total of $25 \%$ of identical twins, who have identical genetic makeup, develop MS. In comparison, only $2 \%$ of fraternal twins, whose genetic makeup is like a brother of sister, develop MS.

Some genetic research in MS focuses on how our bodies are able to recognize foreign substances. For instance, in organ transplantation, the immune system may see the transplanted organ as foreign and reject it. Research into the genetics of MS may show how some people's bodies become confused. This would help us to identify who is more likely to develop illnesses like MS, where the body attacks its own myelin.

See "Multiple sclerosis, inflammation in the brain, and mood" for more information. ${ }^{2}$

HOW MS AFFECTS THE BRAIN Most people think MS is an illness that mostly affects white matter. Studies show that MS affects gray matter as well. When MS affects gray matter, the nerve cells die. Nerve cell death causes a decrease in the volume of the gray matter. A reduction in volume is called atrophy. Years ago, before MRI, an autopsy might show atrophy. Today, MRI can identify atrophy in the living brain. Newer MRIs are able to detect subtle changes even more easily.

If MS primarily affects the white matter, why do nerve cells die? Some scientists believe that an attack on myelin also affects the axon. Some nerve cells cannot live without their axons. When a nerve cell dies due to axonal injury, it is called wallerian degeneration.

Others have proposed that MS affects the nerve cell body directly. In other words, the nerve cell body is destroyed first. Which is correct? Is it the axon first, or is an attack on the cell body the beginning of what we call MS? The answer to this question could lead to a cure of this illness.

As MS affects different parts of the brain, neurologic symptoms appear. Depending on the brain region, these symptoms can be weakness, numbness, or can manifest as changes on in vision or balance. Often, the symptoms come and go (relapsing-remitting). In other people, the symptoms appear, and gradually worsen over time (progressive). The treatments for MS are designed to prevent new symptoms, slow or halt the progression of disease, and to reverse, if possible, the injury that has occurred.

Most textbooks describe 2 types of MS. In one, the symptoms come and go. In between the symptoms, the person may feel fine. This type of MS is called relapsing-remitting MS. The other main type is called progressive MS. This type slowly worsens, resulting in a gradual loss of neurologic function. Some have observed that white matter is more involved in the relapsing-remitting type, while gray matter may be more involved in the gradually progressive form.

More recent literature has made the distinction between these 2 types less clear. Are they separate illnesses? Does one type turn into the other? How do they overlap? The answers to these questions remain unclear.

\section{REFERENCES}

1. Laroni A, Signori A, Maniscalco GT, et al. Assessing association of comorbidities with treatment choice and persistence in MS: a real-life multicenter study. Neurology 2017;89: 2222-2229.

2. Karceski S. Multiple sclerosis, inflammation in the brain, and mood. Neurology 2017;89:e169-e171.

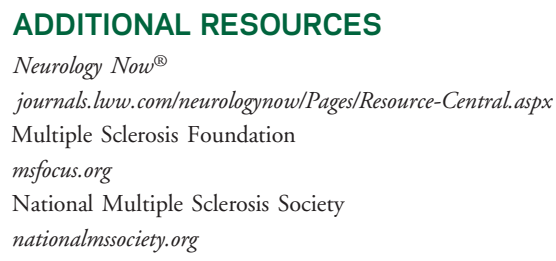




\section{Neurology}

\section{How comorbid conditions affect the choice of treatment in multiple sclerosis Steven Karceski \\ Neurology 2017;89;e265-e267 \\ DOI 10.1212/WNL.0000000000004724}

This information is current as of November 27, 2017

\section{Updated Information \& Services}

References

Subspecialty Collections

Permissions \& Licensing

Reprints including high resolution figures, can be found at: http://n.neurology.org/content/89/22/e265.full

This article cites 2 articles, 2 of which you can access for free at: http://n.neurology.org/content/89/22/e265.full\#ref-list-1

This article, along with others on similar topics, appears in the following collection(s):

All Demyelinating disease (CNS)

http://n.neurology.org/cgi/collection/all_demyelinating_disease_cns Multiple sclerosis

http://n.neurology.org/cgi/collection/multiple_sclerosis

Information about reproducing this article in parts (figures,tables) or in its entirety can be found online at:

http://www.neurology.org/about/about_the_journal\#permissions

Information about ordering reprints can be found online:

http://n.neurology.org/subscribers/advertise

Neurology ${ }^{\circledR}$ is the official journal of the American Academy of Neurology. Published continuously since 1951, it is now a weekly with 48 issues per year. Copyright (O 2017 American Academy of Neurology. All rights reserved. Print ISSN: 0028-3878. Online ISSN: 1526-632X.

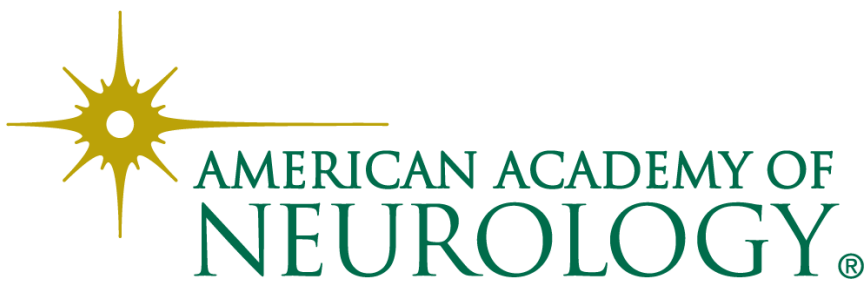

